\title{
MENINGKATKAN KEMAMPUAN METAKOGNITIF SISWA MELALUI PEMBELAJARAN DENGAN PENDEKATAN OPEN-ENDED
}

\author{
Nur Eva Zakiah \\ Program Studi Pendidikan Matematika, FKIP, Universitas Galuh, \\ Jln. R.E. Martadinatan No 150 Ciamis, 46251, Ciamis \\ e-mail: nureva.math@gmail.com
}

\begin{abstract}
Abstrak. Penelitian ini bertujuan untuk mengetahui perbedaan peningkatan kemampuan metakognitif antara siswa yang memperoleh pembelajaran dengan pendekatan openended dan siswa yang memperoleh pembelajaran biasa ditinjau dari keseluruhan maupun berdasarkan kategori kemampuan awal matematis (tinggi, sedang, dan rendah). Penelitian ini adalah penelitian kuasi eksperimen dengan desain kelompok kontrol pretes-postes non equivalent. Populasi dalam penelitian ini adalah seluruh siswa kelas VIII di SMPN 2 Sukahaji Kabupaten Majalengka pada semester genap Tahun Pelajaran 2013/2014. Penentuan kelas eksperimen dan kontrol menggunakan teknik purposive sampling. Untuk mendapatkan data hasil penelitian digunakan instrumen berupa tes kemampuan metakognitif, lembar observasi aktivitas siswa dan guru, serta pedoman wawancara. Analisis data dilakukan dengan menggunakan uji t, uji Mann-Whitney, dan uji ANOVA dua jalur. Hasil penelitian diperoleh: (1) peningkatan kemampuan metakognitif siswa yang memperoleh pembelajaran dengan pendekatan open-ended lebih baik daripada siswa yang memperoleh pembelajaran biasa; (2) ditinjau dari kemampuan awal matematis (KAM) terdapat perbedaan peningkatan kemampuan metakognitif siswa yang memperoleh pembelajaran dengan pendekatan open-ended dan siswa yang memperoleh pembelajaran biasa; (3) tidak terdapat interaksi antara pembelajaran dan KAM terhadap peningkatan kemampuan metakognitif siswa.
\end{abstract}

Kata Kunci: Kemampuan Metakognitif, Pendekatan Open-ended

\section{PENDAHULUAN}

Matematika sebagai salah satu disiplin ilmu mempunyai peranan penting dalam mengembangkan kemampuan peserta didik termasuk kemampuan berpikirnya. Hal ini sesuai dengan Standar Nasional Pendidikan bahwa bahan kajian matematika, antara lain: berhitung; ilmu ukur; dan aljabar dimaksudkan untuk mengembangkan logika dan kemampuan berpikir peserta didik. Menurut Fisher (1995) keberhasilan dalam proses berpikir ditentukan oleh tiga operasi: (1) pemerolehan pengetahuan (input); (2) strategi penggunaan dan pemecahan masalah (output); serta metakognisi dan pengambilan keputusan (control).
Pengembangan kemampuan berpikir dapat dilakukan melalui matematika yang secara substansial memuat pengembangan kemampuan berpikir yang berlandaskan pada kaidah-kaidah penalaran secara logis, kritis, sistematis dan akurat. Kemampuan berpikir tersebut secara umum dikenal sebagai kemampuan berpikir matematis (Suryadi, 2012). Siswa yang telah mempelajari matematika diharapkan mempunyai kemampuan sebagaimana tercantum dalam Permendikbud Nomor 54 Tahun 2013 tentang Standar Kompetensi Lulusan untuk jenjang pendidikan dasar dan menengah. Kompetensi lulusan yang diharapkan dicapai oleh siswa yaitu memiliki pengetahuan faktual, konseptual, prosedural, dan metakognitif. 
Metakognitif menjadi fokus tujuan pembelajaran yang diharapkan dapat dicapai oleh siswa setelah mempelajari matematika. Salah satu kemampuan metakognitif yang sangat penting dalam belajar matematika adalah kemampuan untuk menemukan strategi penyelesaian yang tepat. Melalui metakognitif seseorang berpikir dalam rangka membangun strategi untuk memecahkan masalah (O'Neil \& Brown, 1997).

Pengembangan

kemampuan berpikir khususnya yang mengarah pada kemampuan metakognitif perlu mendapat perhatian serius, karena sejumlah hasil studi (Henningsen \& Stein, 1997; Mullis, et al, 2000) menunjukkan bahwa pembelajaran matematika pada umumnya masih berfokus pada pengembangan kemampuan berpikir tahap rendah yang bersifat prosedural. Lebih lanjut Mullis, et al (2000) menjelaskan bahwa sebagian besar pembelajaran matematika belum berfokus pada pengembangan kemampuan matematis siswa. Secara umum, pembelajaran matematika masih terdiri atas rangkaian kegiatan yang diawali dengan sajian masalah oleh guru, selanjutnya dilakukan demonstrasi penyelesaian masalah, dan terakhir guru meminta siswa untuk melakukan latihan penyelesaian soal.

Penelitian yang dilakukan Latifah (2012) diperoleh hasil rerata skor postes kemampuan metakognisi siswa SMP melalui pembelajaran model CORE sebesar 48,16\% dari skor ideal. Hasil penelitian Alhadad (2010) menunjukkan bahwa rerata skor postes kemampuan pemecahan masalah SMP yang mendapat pembelajaran dengan pendekatan openended sebesar $42,89 \%$ dari skor ideal. Pemaparan tersebut menunjukkan bahwa penelitian-penelitian terdahulu belum memberikan hasil yang diharapkan. Sebagai peneliti pendidikan, guru harus terus berupaya merancang pembelajaran yang dapat memberikan hasil yang memuaskan.
Berdasarkan hasil observasi yang dilakukan peneliti di salah satu SMPN di Kabupaten Majalengka, siswa belum mampu memberikan alternatif solusi dalam menyelesaikan permasalahan. Selain dari observasi kelas, data diperoleh dari hasil kerja siswa. Kurangnya kemampuan matematis siswa dalam mengerjakan soal dikarenakan siswa belum mampu melakukan perencanaan yang baik, memilih strategi yang tepat untuk menyelesaikan soal, dan mengevaluasi jawaban yang sudah diperolehnya. Hal ini menunjukkan masih lemahnya kemampuan berpikir matematis siswa khususnya kemampuan metakognitif.

Kemampuan metakognitif berkaitan dengan kemampuan siswa membuat prediksi, perencanaan, pemantauan dan evaluasi pada proses penyelesaian masalah. Selain itu siswa harus mampu memilih strategi yang tepat untuk menyelesaikan soal yang diberikan. Siswa yang memiliki kemampuan metakognitif rendah akan berujung pada kegagalan pemecahan masalah, sedangkan siswa yang memiliki kemampuan metakognitif baik akan meningkatkan kemampuan pemecahan masalah non rutin (Yoong, 2002).

Karena pentingnya kemampuan metakognitif dalam mengembangkan kemampuan berpikir matematis tingkat tinggi dan bila dikembangkan dengan baik akan berdampak kepada peningkatan kualitas prestasi belajar siswa. Kemudian muncul pertanyaan tentang usaha yang harus dilakukan oleh guru untuk meningkatkan kemampuan metakognitif siswa. Mulyana (2008) menambahkan pembelajaran yang sesuai dengan tujuan pembelajaran matematika, dan rekomendasi NCTM, Depdiknas, UNESCO dan para pakar pendidikan adalah pembelajaran berbasis masalah, seperti pembelajaran tidak langsung, pembelajaran kontekstual, pembelajaran open-ended, pembelajaran matematik realistik. 
Pembelajaran yang diharapkan dapat meningkatkan kemampuan metakognitif siswa adalah pembelajaran dengan menggunakan pendekatan openended. Pendekatan open-ended merupakan pendekatan pembelajaran yang menggunakan masalah terbuka yang dapat dijawab dengan banyak cara/metode penyelesaian atau jawaban benar yang beragam. Dengan keberagaman cara penyelesaian dan jawaban tersebut, maka memberikan keleluasaan kepada siswa dalam menyelesaikan masalah. Menurut Shimada (1997) peran guru dalam pendekatan open-ended yaitu memberikan suatu situasi ataupun permasalahan kepada siswa yang proses penyelesaian ataupun solusinya tidak ditentukan dalam satu cara.

Pembelajaran dengan menggunakan masalah atau soal open-ended dapat memberikan siswa banyak pengalaman dalam menafsirkan masalah dan mungkin pula membangkitkan gagasan-gagasan yang berbeda dalam menyelesaikan suatu masalah (Silver, 1997). Hal ini tentunya akan membuka kemungkinan siswa menggunakan berbagai strategi penyelesaian untuk mencari solusi dari masalah yang dihadapinya. Selain itu, pembelajaran ini membantu siswa melakukan perencanaan, penyelesaian, monitoring proses menyelesaikan masalah dan evaluasi terhadap hasil yang telah dilakukan, sehingga melalui pembelajaran dengan pendekatan open-ended diharapkan dapat meningkatkan kemampuan metakognitif.

Pada kegiatan pembelajaran di kelas, pembelajaran biasa juga masih baik untuk digunakan. Pembelajaran biasa identik dengan pembelajaran yang didominasi oleh guru, atau dengan kata lain pembelajaran yang teacher centered. Menurut Ruseffendi (2006) pembelajaran biasa yang sering dipakai pada pengajaran matematika diawali dengan pemberian informasi atau ceramah. Oleh karena itu dalam menyampaikannya digunakan metode ceramah atau ekspositori.
Fokus dalam penelitian ini, selain dari aspek pembelajaran, aspek kemampuan awal siswa menjadi perhatian penulis. Informasi mengenai pengetahuan awal matematis siswa digunakan untuk menentukan tingkat Kemampuan Awal Matematis (KAM) siswa (tinggi, sedang, rendah). Tingkatan KAM diperoleh berdasarkan kemampuan matematis siswa dari hasil ulangan harian, hasil ulangan tengah semester dan hasil ulangan akhir semester. Tujuan digunakan KAM yaitu untuk melihat perbedaan masing-masing kategori kemampuan awal matematis antara kedua kelas (open-ended dan biasa).

Berdasarkan latar belakang yang telah dijelaskan di atas, penulis melakukan penelitian tentang peningkatan kemampuan metakognitif siswa yang pembelajarannya menggunakan pendekatan open-ended dan siswa yang menggunakan pembelajaran biasa.

Penelitian ini bertujuan untuk mengetahui: (1) peningkatan kemampuan metakognitif siswa yang memperoleh pembelajaran dengan pendekatan openended lebih baik daripada siswa yang memperoleh pembelajaran biasa; (2) perbedaan peningkatan kemampuan metakognitif siswa yang memperoleh pembelajaran dengan pendekatan openended dan siswa yang memperoleh pembelajaran biasa berdasarkan kategori kemampuan awal matematis (tinggi, sedang, dan rendah); (3) interaksi antara pembelajaran dan kemampuan awal matematis (tinggi, sedang, dan rendah) terhadap peningkatan kemampuan metakognitif siswa.

\section{KEMAMPUAN METAKOGNITIF}

Metakognisi merupakan suatu istilah yang diperkenalkan oleh John Flavell pada tahun 1976. Istilah ini digunakan Flavell (1976) untuk memperkenalkan metamemori dalam penelitiannya tentang proses ingatan anak. Weinert dan Kluwe (Livingstone, 1997) mengemukakan bahwa metakognisi 
berasal dari kata "meta" dan "kognisi". Meta artinya setelah atau melebihi, sedangkan kognisi artinya keterampilan yang berhubungan dengan proses berpikir. Metakognisi merupakan second-order cognition yang berarti berpikir tentang berpikir, pengetahuan tentang pengetahuan atau refleksi tentang tindakan-tindakan.

Livingstone (1997) mendefinisikan metakognisi sebagai thinking about thinking atau berpikir tentang berpikir. Metakognisi merupakan kemampuan berpikir, yang menjadi objek berpikirnya adalah proses berpikir yang terjadi pada diri sendiri. Sementara itu Matlin (1998) dalam bukunya yang diberi judul Cognition, menyatakan: "Metacognition is our knowledge, awareness, and control of our cognitive process". Metakognisi, menurut Matlin adalah pengetahuan, kesadaran, dan kontrol terhadap proses kognitif yang terjadi pada diri sendiri.

Brown (Hacker, 2009) mengidentifikasi terdapat dua kemampuan metakognitif yaitu pengetahuan tentang kognisi, mengelola dan meningkatkan kognisi atau disebut kemandirian. Pengetahuan kognisi disebut sebagai selfunderstanding, meliputi mengetahui apa yang kamu ketahui dan kamu tidak ketahui. Hal ini ditunjukkan melalui: bagaimana kamu belajar, melakukan proses, dan meningkatkan pemahaman. Kemampuan mengelola dan meningkatkan kognisi disebut sebagai kemandirian. Hal ini meliputi perencanaan, pemantauan, refleksi, dan berpikir bagaimana dapat menjadi lebih baik.

Bidang kajian metakognisi menurut Boekaerts (Panaoura, et. al: 2009) terbagi menjadi dua, yaitu pengetahuan tentang kognitif (knowledge about cognition) dan pengaturan kognitif (regulation of cognition). Pengetahuan metakognisi adalah pengetahuan yang digunakan untuk mengarahkan proses berpikir kita sendiri. Pengetahuan metakognisi meliputi pengetahuan tentang: variabel orang; variabel tugas; dan variabel strategi. Pengarahan proses berpikir ini dapat dilakukan melalui aktivitas perencanaan (planning), pemantauan (monitoring) dan pengevaluasian (evaluation). Aktivitasaktivitas ini disebut sebagai strategi metakognitif atau kemampuan metakognitif yang dapat membantu menyelesaikan masalah yang dihadapi. Penggunaan strategi metakognitif ini merupakan pengalaman metakognitif atau disebut dengan pengaturan metakognitif.

Flavell (Livingstone, 1997) menandai empat komponen metakognitif, yaitu: (1) pengetahuan metakognitif (metacognitive knowledge); (2) tujuan metakognitif (metacognitive goal); (3) strategi metakognitif (metacognitive strategies); (4) pengalaman atau regulasi metakognitif (metacognitive experiences or regulation).

\section{PENDEKATAN OPEN-ENDED}

Pendekatan open-ended pertama kali dikenalkan dan dikembangkan di Jepang sekitar tahun 1970-an dengan sebutan metode "open-approach". Munculnya pendekatan open-ended ini sebagai reaksi atas pendidikan matematika sekolah saat itu yang aktivitas kelasnya disebut dengan "issei jugyow" (frontal teaching): guru menjelaskan konsep baru di depan kelas kepada para siswa, kemudian memberikan contoh untuk penyelesaian beberapa soal. Pendekatan ini lahir dari hasil penelitian yang dilakukan Shigeru Shimada, Yoshiko Yashimoto, dan Kenichi Shibuya (Nohda, 2000).

Pendekatan

open-ended memberikan kesempatan kepada siswa untuk menginvestigasi berbagai strategi dan cara yang diyakininya sesuai dengan kemampuan yang dimilikinya untuk mengelaborasi permasalahan. Dengan seperti ini kemampuan berpikir matematis siswa dapat berkembang lebih kreatif dan setiap siswa terkomunikasikan melalui proses pembelajaran. Inilah yang menjadi pokok pikiran pembelajaran dengan pendekatan open-ended, yaitu pembelajaran yang membangun kegiatan interaktif antara matematika dengan siswa 
sehingga siswa terdorong untuk menjawab permasalahan melalui berbagai strategi.

$$
\text { Menurut Nohda }
$$

pembelajaran dengan menggunakan pendekatan open-ended mengasumsikan tiga prinsip, yakni sebagai berikut: (1) related to the autonomy of student' activities. If requires that we should appreciate the value of student' activities for fear of being just non-interfering. (2) related to evolutionary and integral nature of mathematical knowledge. Content mathematics is theoretical and systematic. Therefore, the more essential certain knowledge is, the more comprehensively it derives analogical, special, and general knowledge. Metaphorically, more essential knowledge opens the door ahead more widely. At the same time, the essential original knowledge can reflected on many times later in the course of evolution of mathematical knowledge. This reflection on the original knowledge is a driving force to continue to step forward across the door, (3) related to teachers' expedient decision-making in class. In mathematics class, teachers often encounter students' unexpected ideas. In this bout, teachers have an important role to give the ideas full play, and to take into account that other students can also understand real amount of the unexpected ideas.

Masalah yang diambil untuk tugas matematis dengan pendekatan open-ended dapat diperoleh dari masalah yang konstektual (real world) dan masalah dalam matematika (Shimada, 1997). Masalah konstekstual diambil dari masalah-masalah keseharian atau masalahmasalah yang dapat dipahami oleh pikiran siswa. Dengan masalah itu siswa akan dibawa kepada konsep matematika melalui reinvetion atau melalui discovery. Selanjutnya, jenis masalah yang digunakan adalah masalah yang bukan rutin yang bersifat terbuka. Sedangkan dasar keterbukaanya (openness) dapat diklasifikasikan kedalam tiga tipe, yakni: (1) process is open: tipe soal mempunyai banyak cara penyelesaian yang benar, (2) end product are open: tipe soal mempunyai jawaban benar yang banyak (multiple), (3) ways to develop are open: ketika siswa telah selesai menyelesaikan masalahnya, mereka dapat mengembangkan masalah baru dengan mengubah kondisi dari masalah yang pertama (asli). Dengan demikian pendekatan ini menyelesaikan masalah dan juga memunculkan masalah baru (from problem to problem).

Pemberian masalah terbuka berpeluang untuk membantu siswa dalam memahami dan mengelaborasi ide-ide matematis sejauh dan sedalam mungkin. Hal ini sejalan dengan pendapat Ruseffendi (2006) mengungkapkan bahwa jawaban masalah terbuka dapat bermacammacam jawaban tidak terduga. Pembelajaran dengan pendekatan openended, guru memberikan permasalahan kepada siswa yang solusinya atau jawabannya tidak perlu ditentukan hanya satu cara. Kegiatan ini dapat mengakomodasi kesempatan siswa untuk melakukan segala sesuatu secara bebas sesuai kehendak mereka (Suherman, 2008). Hal ini menunjukkan bahwa penyajian masalah-masalah terbuka juga mendorong siswa untuk berpikir lebih kritis, terbuka, dan mampu bekerja sama dan berkompeten dalam pemecahan masalah dan dalam berkomunikasi secara logis dan argumentatif.

\section{METODE PENELITIAN}

Penelitian ini bertujuan untuk melihat perbedaan peningkatan kemampuan metakognitif antara siswa yang memperoleh pembelajaran dengan pendekatan open-ended dan siswa yang memperoleh pembelajaran biasa. Metode penelitian dalam penelitian ini adalah kuasi eksperimen. Pada penelitian ini subjek tidak dikelompokkan secara acak, tetapi keadaan subjek diterima sebagaimana adanya (Ruseffendi, 2010).

Populasi dalam penelitian ini adalah seluruh siswa kelas VIII di SMPN 2 Sukahaji Kabupaten Majalengka yang 
dilaksanakan pada semester II (genap) Tahun Pelajaran 2013/2014. Penentuan kelas eksperimen dan kontrol dengan menggunakan teknik purposive sampling. Berdasarkan teknik tersebut diperoleh sampel sebanyak dua kelas yaitu kelas VIII B sebagai kelas eksperimen sebanyak 34 siswa dan kelas VIII D sebagai kelas kontrol sebanyak 32 siswa. Pembelajaran pada kelas eksperimen menggunakan pendekatan open-ended, sedangkan kelas kontrol menggunakan pembelajaran biasa.

Variabel penelitian dalam penelitian ini melibatkan tiga jenis variabel yakni variabel bebas yaitu pendekatan openended dan pembelajaran biasa, variabel terikat yaitu kemampuan metakognitif, serta variabel kontrol yaitu KAM (tinggi, sedang, dan rendah).

\section{HASIL DAN PEMBAHASAN Hasil Penelitian}

Berdasarkan hasil skor pretes dan postes, selanjutnya dihitung $\mathrm{N}$-gain kemampuan metakognitif pada kelas eksperimen maupun kelas kontrol Deskripsi kemampuan metakognitif siswa disajikan dalam Tabel 1 berikut.

Tabel 1. Deskripsi Statistik Data Kemampuan Metakognitif Siswa

Berdasarkan Kemampuan Awal Matematis

\begin{tabular}{|c|c|c|c|c|c|c|c|c|c|c|c|c|}
\hline \multirow{2}{*}{$\begin{array}{c}\text { Kategori } \\
\text { KAM }\end{array}$} & \multicolumn{9}{|c|}{ Kelas Open-ended } & \multicolumn{8}{c|}{ Kelas Biasa } \\
\cline { 2 - 14 } & Pretes & \multicolumn{2}{|c|}{ Postes } & N-Gain & \multicolumn{2}{c|}{ Pretes } & \multicolumn{2}{c|}{ Postes } & \multicolumn{2}{c|}{ N-Gain } \\
\cline { 2 - 13 } & $\bar{x}$ & $S$ & $\bar{x}$ & $S$ & $\bar{x}$ & $s$ & $\bar{x}$ & $s$ & $\bar{x}$ & $s$ & $\bar{x}$ & $s$ \\
\hline Tinggi & 1,90 & 1,66 & 12,40 & 3,09 & 0,59 & 0,15 & 1,67 & 1,22 & 10,11 & 2,09 & 0,46 & 0,09 \\
\hline Sedang & 1,57 & 1,28 & 9,79 & 2,12 & 0,45 & 0,09 & 1,61 & 1,19 & 8.38 & 1,80 & 0,37 & 0,07 \\
\hline Rendah & 1,80 & 1,32 & 8,40 & 1,71 & 0,360 & 0,06 & 1,20 & 103 & 7,20 & 1,39 & 0,32 & 0,05 \\
\hline Seluruh & 1,74 & 1,38 & 10,15 & 2,78 & 0,46 & 0,13 & 1,50 & 1,14 & 8,50 & 2,06 & 0,38 & 0,09 \\
\hline \multicolumn{1}{|c|}{ Skor Maksimum Ideal = 20 } \\
\hline
\end{tabular}

Berdasarkan tabel di atas menunjukkan bahwa hasil peningkatan kemampuan metakognitif secara keseluruhan pada kelas open-ended sebesar 0,46 , dengan kualitas peningkatan level sedang, dan peningkatan kemampuan metakognitif secara keseluruhan pada kelas biasa sebesar 0,38, dengan kualitas peningkatan level sedang. Untuk mengetahui peningkatan kemampuan metakognitif dilakukan uji perbedaan skor $\mathrm{N}$-gain. Sebelum dilakukan uji perbedaan skor $\mathrm{N}$-gain terlebih dahulu melakukan uji normalitas dan uji homogenitas. Berdasarkan hasil uji normalitas untuk kelas open-ended dan kelas biasa data tidak berdistribusi normal.

Hipotesis pada penelitian ini yaitu "Peningkatan kemampuan metakognitif siswa yang memperoleh pembelajaran dengan pendekatan open-ended lebih baik daripada siswa yang memperoleh pembelajaran biasa". Hipotesis tersebut adalah hipotesis satu arah, dengan kriteria pengujian menurut Uyanto (2006) jika $\frac{1}{2}$ sig. $(2-$ tailed $)=$ sig. $(1-$ tailed $)>0,05$ maka $\mathrm{H}_{0}$ diterima. Hasil perhitungan uji perbedaan skor $\mathrm{N}$-gain kemampuan metakognitif menggunakan uji MannWhitney disajikan dalam Tabel 2 berikut.

Tabel 2. Hasil Uji Perbedaan Skor N-Gain Kemampuan Metakognitif

\begin{tabular}{|c|c|c|c|c|}
\hline Zhitung & Mann-Whitney & Sig (2-tailed) & Sig (1-tailed) & Ket \\
\hline$-2,857$ & 322 & 0,004 & 0,002 & $\mathrm{H}_{0}$ ditolak \\
\hline
\end{tabular}

Berdasarkan tabel di atas diperoleh nilai nilai sig. $<\alpha=0,05$ yaitu 0,002 . Hal ini menunjukkan bahwa $\mathrm{H}_{0}$ ditolak, dengan demikian hipotesis terbukti bahwa peningkatan kemampuan metakognitif siswa yang mendapat pembelajaran dengan pendekatan open-ended lebih baik daripada siswa yang mendapat pembelajaran biasa.

Pengujian perbedaan skor N-gain kemampuan metakognitif berdasarkan kategori KAM dilakukan untuk 
mengetahui apakah terdapat perbedaan peningkatan kemampuan metakognitif siswa yang memperoleh pembelajaran dengan pendekatan open-ended dan siswa yang memperoleh pembelajaran biasa ditinjau dari kategori KAM.

Hipotesis yang diajukkan dalam penelitian ini adalah "Terdapat perbedaan peningkatan kemampuan metakognitif antara siswa yang memperoleh pembelajaran dengan pendekatan openended dan siswa yang memperoleh pembelajaran biasa berdasarkan kategori KAM (tinggi, sedang, dan rendah)".

.Tabel 3. Perbedaan Peningkatan Kemampuan Metakognitif Berdasarkan KAM dan Pembelajaran

\begin{tabular}{|c|c|c|c|c|}
\hline Kategori KAM & Pembelajaran & t & sig. & Ket \\
\hline Tinggi & Open-ended-Biasa & 2,181 & 0,045 & $\mathrm{H}_{0}$ Ditolak \\
\hline Sedang & Open-ended-Biasa & 2,606 & 0,015 & $\mathrm{H}_{0}$ Ditolak \\
\hline Rendah & Open-ended - Biasa & 1,812 & 0,087 & $\mathrm{H}_{0}$ Diterima \\
\hline
\end{tabular}

Berdasarkan tabel di atas dapat disimpulkan bahwa siswa untuk kategori KAM tinggi dan sedang yang memperoleh pembelajaran dengan pendekatan openended memiliki peningkatan kemampuan metakognitif lebih baik daripada siswa yang memperoleh pembelajaran biasa. Sementara pada kategori KAM rendah tidak terdapat perbedaan peningkatan kemampuan metakognitif. Temuan ini mengindikasikan bahwa siswa kategori KAM tinggi dan sedang memperoleh manfaat lebih dari pembelajaran dengan pendekatan open-ended.

Tabel 4. Hasil Uji Interaksi KAM dan Pembelajaran pada Peningkatan Kemampuan Metakognitif

\begin{tabular}{|c|c|c|}
\hline Faktor & F & Sig. \\
\hline Kategori Pembelajaran * KAM & 0,977 & 0,382 \\
\hline
\end{tabular}

Berdasarkan tabel di atas diperoleh nilai sig. $>\alpha=0,05$ yaitu 0,382 sehingga $\mathrm{H}_{0}$ diterima. Hal ini berarti tidak terdapat interaksi antara pembelajaran dan KAM terhadap peningkatan kemampuan metakognitif. Temuan ini menunjukkan bahwa pengaruh faktor pembelajaran terhadap peningkatan kemampuan metakognitif tidak bergantung pada faktor KAM. interaksi antara pembelajaran dan KAM terhadap peningkatan kemampuan metakognitif siswa, dilakukan uji ANOVA dua jalur dengan kriteria pengujian, jika sig. $>\alpha=0,05$, maka $\mathrm{H}_{0}$ diterima. Hipotesis penelitian yang diajukan dalam penelitian ini adalah "Terdapat interaksi antara pembelajaran (open-ended dan biasa) dan KAM (tinggi, sedang, dan rendah) terhadap peningkatan kemampuan metakognitif siswa". Ringkasan hasil uji ANOVA dua jalur disajikan pada Tabel 4 berikut.
Berdasarkan hasil uji normalitas dan homogenitas diperoleh N-gain kemampuan metakognitif berdasarkan kategori KAM untuk kedua kelas berdistribusi normal dan bervarians homogen. Untuk mengetahui ada atau tidaknya perbedaan peningkatan kemampuan metakognitif siswa berdasarkan kategori KAM digunakan uji t (Independent sample t-test). Rangkuman uji $\mathrm{t}$ tersebut dapat dilihat pada Tabel 3 berikut. 
skor N-gain siswa yang memperoleh pembelajaran dengan pendekatan openended lebih baik dari siswa yang memperoleh pembelajaran biasa. Hasil tersebut memberikan gambaran bahwa pembelajaran open-ended dapat meningkatkan kemampuan metakognitif siswa. Kualitas peningkatan kemampuan metakognitif untuk kedua kelas (openended dan biasa) berada pada level sedang.

Setelah dilakukan uji perbedaan peningkatan kemampuan metakognitif berdasarkan kategori KAM dengan menggunakan uji t, menunjukkan bahwa KAM memberikan pengaruh yang signifikan terhadap peningkatan kemampuan metakognitif. Siswa pada kategori KAM tinggi dan sedang yang memperoleh pembelajaran dengan pendekatan open-ended memiliki peningkatan kemampuan metakognitif lebih baik daripada siswa yang memperoleh pembelajaran biasa, dengan kualitas peningkatan berada pada level sedang. Sementara pada kategori KAM rendah tidak terdapat perbedaan peningkatan kemampuan metakognitif, dengan kualitas peningkatan berada pada level sedang. Temuan ini mengindikasikan bahwa siswa kategori KAM tinggi dan sedang memperoleh manfaat lebih dari pembelajaran dengan pendekatan openended dalam meningkatkan kemampuan metakognitif.

Mengapa siswa kelompok tinggi dan sedang memperoleh manfaat lebih dari pembelajaran dengan pendekatan openended? Salah satu faktor yang dapat menjelaskan hal tersebut adalah karateristik bahan ajar yang digunakan. Bahan ajar yang digunakan dalam penelitian ini adalah LKS yang memuat masalah-masalah terbuka. Diduga kuat, karateristik bahan ajar demikian sangat membantu siswa dalam membangun pengetahuan dan sekaligus mengembangkan metakognitif. Hal demikian juga didukung oleh hasil pengamatan peneliti terhadap proses pembelajaran pada siswa kelompok tinggi dan sedang yang menunjukkan terdapat beberapa siswa yang mampu memberikan alternatif solusi dari permasalahan di LKS.

Pemberian masalah terbuka kepada siswa bukan hanya berorientasi untuk mendapatkan jawaban atau hasil akhir tetapi lebih menekankan pada bagaimana siswa sampai pada suatu jawaban, siswa dapat mengembakan cara/metode, dan bahkan siswa dapat menemukan jawaban yang berbeda dalam menyelesaikan masalah. Hal tersebut memberikan peluang pada siswa untuk melakukan elaborasi yang lebih besar, sehingga dapat mengembangkan pemikiran matematis siswa, serta membantu perkembangan aktivitas yang kreatif dari siswa dalam memunculkan kemampuan metakognitif dalam menyelesaikan masalah.

Hasil penelitian ini sejalan dengan penelitian Alhadad (2010) yang menemukan bahwa dengan menerapkan pembelajaran open-ended melalui penggunaan masalah terbuka dapat melatih siswa dalam memecahkan masalah sesuai dengan cara atau metode yang mereka kuasai. Penelitian ini juga menyimpulkan bahwa kemampuan pemecahan masalah siswa menggunakan pendekatan openended lebih baik daripada siswa yang memperoleh pembelajaran biasa.

Hasil penelitian ini sejalan dengan penelitian Aguspinal (2011) tentang pembelajaran dengan pendekatan openended yang menyimpulkan bahwa ditemukannya beberapa alternatif jawaban yang benar dapat meningkatkan semangat belajar siswa sehingga mereka termotivasi untuk mengeksplor kompetensi yang ada secara menyeluruh. Penelitian ini juga menyimpulkan bahwa kemampuan berpikir kreatif siswa menggunakan pendekatan open-ended lebih baik daripada siswa yang memperoleh pembelajaran biasa konvensional.

Hasil temuan ini juga sesuai dengan rekomendasi dari NCTM yang menganjurkan guru untuk mendorong siswa menerapkan strategi yang beragam dalam menyelesaikan masalah. Strategi ini 
termasuk memanipulasi, mencoba-coba (trial and error), mencoba kasus per kasus, menebak dan mengecek, mendaftar berbagai kemungkinan, mengumpulkan dan mengorganisasi data, mencari suatu pola, menggambarkan suatu diagram, dan bekerja mundur (NCTM, 1989 dan NCTM, 2000). Bahkan secara lebih tegas NCTM (1989) menyatakan bahwa menghadirkan pada siswa permasalahan open-ended adalah suatu karakteristik yang sangat penting dari pemecahan masalah.

Selanjutnya bagi siswa kategori KAM rendah tidak memperoleh manfaat lebih dari pembelajaran dengan pendekatan open-ended dalam meningkatkan kemampuan metakognitif. Hasil ini menunjukkan bahwa untuk meningkatkan kemampuan metakognitif siswa kelompok rendah lebih bagus menggunakan pembelajaran biasa. Berdasarkan hasil wawancara perwakilan siswa kelompok rendah kedua kelas (open-ended dan biasa) diperoleh informasi bahwa siswa kelompok rendah kelas open-ended mengalami kesulitan mengikuti proses pembelajaran. Hal ini diakibatkan tidak terbiasanya siswa kelompok rendah menerima soal dengan jenis soal terbuka. Kebiasaan belajar yang dialami dalam waktu yang cukup lama sulit dirubah dalam waktu yang singkat.

Kondisi ini dapat dipahami, bahwa kemampuan awal matematis yang dimiliki siswa mempengaruhi peningkatan kemampuan metakognitif. Hal ini disebabkan siswa yang memiliki kemampuan prasyarat tinggi dan sedang lebih siap untuk mengerjakan jenis soal terbuka. Keinginan untuk mengerjakan soal lebih tinggi, ini ditunjukkan dengan keaktifan siswa kelompok tinggi dan sedang untuk bertanya dan memberikan gagasan.

Berdasarkan uji interaksi antara pembelajaran dan KAM (tinggi, sedang, dan rendah) terhadap peningkatan kemampuan metakognitif menyimpulkan bahwa tidak terdapat interaksi antara pembelajaran dan KAM terhadap peningkatan kemampuan metakognitif siswa. Temuan tidak ada interaksi menunjukkan bahwa pembelajaran dengan pendekatan OE relatif sesuai untuk meningkatkan kemampuan metakognitif pada semua kategori KAM.

\section{SIMPULAN}

Berdasarkan hasil analisis, temuan, dan pembahasan yang telah disajikan sebelumnya, diperoleh kesimpulan sebagai berikut: (1) peningkatan kemampuan metakognitif siswa yang mendapat pembelajaran dengan pendekatan openended lebih baik daripada siswa yang mendapat pembelajaran biasa. Kualitas peningkatan kemampuan metakognitif siswa kedua kelas (open-ended dan biasa) berada pada level sedang; (2) terdapat perbedaan peningkatan kemampuan metakognitif siswa yang memperoleh pembelajaran dengan pendekatan openended dan siswa yang memperoleh pembelajaran biasa berdasarkan kategori KAM (tinggi, sedang, dan rendah). Siswa kategori KAM tinggi dan sedang yang memperoleh pembelajaran dengan pendekatan open-ended memiliki peningkatan kemampuan metakognitif lebih baik daripada siswa kategori KAM tinggi dan sedang yang memperoleh pembelajaran biasa, dengan kualitas peningkatan berada pada level sedang; (3) tidak terdapat interaksi antara pembelajaran (open-ended dan biasa) dan KAM (tinggi, sedang, dan rendah) terhadap peningkatan kemampuan metakognitif. Untuk meningkatkan kemampuan metakognitif siswa pada setiap kategori KAM lebih optimal menggunakan pendekatan open-ended.

\section{DAFTAR PUSTAKA}

Alhadad, S F. (2010). Meningkatkan Kemampuan Representasi Multipel Matematis, Pemecahan Masalah Matematis dan Self Esteem Siswa SMP melalui Pembelajaran dengan 
Pendekatan Open-ended. Disertasi. UPI: Tidak dipublikasikan.

Aguspinal. (2011). Peningkatan Kemampuan Berpikir Kreatif dan Komunikasi Matematis Siswa SMA melalui Pendekatan Open-ended dengan Strategi Group-To-Group. Tesis. UPI: Tidak dipublikasikan.

Dunlosky, J \& Metcalfe, J. (2009). Metacognition. California: Sage Publications.

Fisher, R. (1995). Teaching Children to Think. Hongkong: Stanley Thornes Ltd.

Flavell, J. H. (1976). Metacognition and cognitive monitoring, A new area of cognitive developmental inquiry, American Psychologist, 34, pp.906911.

Hacker, D. J., Dunlosky, J. \& Graesser, A. C., (2009). Handbook of Metacognition in Education. New York: Routledge.

Henningsen, M. \& Stein, M. K. (1997). Mathematical tasks and student cognition: Classroom-based factors that support and inhibit high-level mathematical thinking and reasoning. Journal for Research in Mathematics Education, 28, 524549.

Latifah, R. (2012). Pengaruh Model 'Core' (Connecting,

Organizing,

Reflecting, Extending) dalam Pembelajaran Matematika dengan Pendekatan Kontekstual untuk Meningkatkan Kemampuan Metakognisi Siswa SMP. Skripsi pada UPI: Tidak Dipublikasikan.

Livingstone, J A. (1997). Metacognitive An Overview. [Online]. Tersedia http://www.gse.buffalo.edu/fas/shu ell/CEP564/Metacog.html [23 Desember 2011].
Matlin, M. W. (1998). Cognition. Philadelphia: Harcourt Brace College Publisher.

Mullis, I. V. S., Martin, M. O., Gonzales, E. J., Gregory, K. D., Garden, R. A., O'Connor, K. M., Krostowski, S. J., \& Smith, T. A. (2000). TIMSS 1999: International Mathematics Report. Boston: ISC.

Mulyana, T. (2008). Pembelajaran Analitik Sintetik untuk Meningkatkan Kemampuan Berpikir Kritis dan Kreatif Matematik Siswa Sekolah Menengah Atas. Bandung: Desertasi UPI.Tidak diterbitkan.

Nohda, N., (2000). Learning and teaching through open-ended approacrh method. Dalam Tadao Nakahara dan Masataka Koyama (editor) Proceeding of the 24th of the International Group for the Psychology of Mathematics Education. Hiroshima: Hiroshima University.

National Council of Teachers of Mathematics (NCTM). (2009). Focus in High School Mathematics: Reasoning and Sense Making. Reston, VA: NCTM.

O’Neil Jr, H.F. \& Brown, R.S. (1997). Differential Effects of Question Formats in Math Assessment on Metacognition and Affect. Los Angeles: CRESST-CSE University of California.

Panaoura, A., Gagatsis, A., \& Demetriou, A. (2009). An Intervention to the Metacognitive Performance: SelfRegulation in Mathematics and Mathematical Modelling. Acta Didactica Universitatis Comencianae Mathematics, Issue 9, 63-79.

Ruseffendi, E. T. (2006). Pengantar Kepada Membantu Guru Mengembangkan Kompetensinya 
dalam Pengajaran Matematika untuk Meningkatkan CBSA.

Bandung: Tarsito.

(2010). Dasar-dasar Penelitian Pendidikan dan Bidang Non-Eksakta Lainnya. Bandung: Tarsito.

Shimada, B. (1997). The Open-Ended Approach A New Proposal for Teaching Mathematics. NCTM.

Silver, E. A. 1997. Fostering Creativity through Instruction Rich in Mathematical Problem Solving and Problem Posing. [Online]. Tersedia: http://www.fizkarlsruhe.de/fiz/publi cations/zdm/2dm97343.pdf.

Suherman, E. (2008). Buku Suplemen Perkuliahan Strategi Belajar Mengajar, Model Belajar dan Pembelajaran Matematika. Jurusan Pendidikan Matematika FPMIPA UPI. Tidak diterbitkan.

Suryadi, D. (2012). Membangun Budaya Baru dalam Berpikir Matematika. Bandung: Rizqi Press.

Uyanto, Stanislaus S. (2006). Pedoman Analisis Data dengan SPSS. Yogyakarta: Graha Ilmu.

Yoong, W.K. (2002). Helping Your Students to Become Metacognitive in Mathematics: A Decade Later. [Online] tersedia dalam http://intranet.moe.edu.sg/maths/Ne wsletter/fourthIssue/vol2No5.html. 